
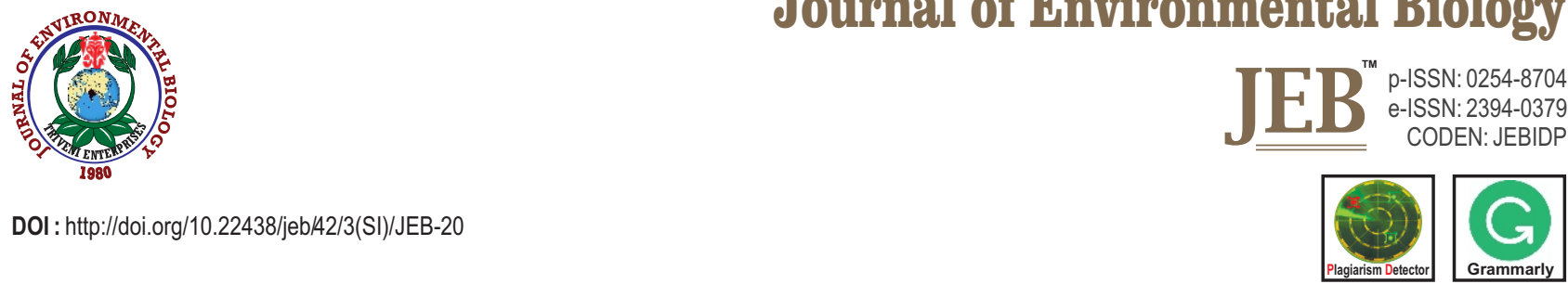

\title{
Adaptation and taxonomic value of leaf anatomical characteristics of selected Ipomoea L. species
}

\author{
T. Noraini ${ }^{1 *}$, A.J. Amirul-Aiman ${ }^{1,2}$, A.R. Ruzi ${ }^{1}$, Bunawan, H. $^{3}$ and S.F. Nurdiana ${ }^{1}$ \\ 'Department of Biological Sciences and Biotechnology Faculty of Science and Technology, Universiti Kebangsaan Malaysia, Bangi, 43600, Malaysia \\ ${ }^{2}$ Department of Environmental Sciences, Faculty of Environmental Studies, Universiti Putra Malaysia, Serdang, 43400, Malaysia \\ ${ }^{3}$ Institute of Biological System, Universiti Kebangsaan Malaysia, Bangi, 43600, Malaysia \\ *Corresponding Author Email : ntalip@ukm.edu.my
}

\begin{abstract}
Aim: To investigate the taxonomic value of leaf anatomical characteristics and to determine the anatomical features that enabled the species to adapt to different environmental conditions.

Methodology: Three methods were applied for leaf anatomy observation: sectioning using a sliding microtome, leaf clearing and epidermal peels.

Results: The findings showed some common anatomical characteristics shared in all species studied, such as incomplete leaf venation, the presence of trichome and schlerenchyma cells, and the presence of mucilaginous idioblast cells in the petiole and midrib. Straight-to-sinuous anticlinal cell walls, amphistomatic leaves, and three types of stomata: parasitic, anomocytic and staurocytic were on the abaxial side of leaf lamina in this study. Peltate and capitate glandular trichome, as well as simple trichome, were all present in the petiole, midrib and lamina. However, peltate glandular trichome were only found in the root of $I$. triloba. Druses were observed in all species, except $I$. batatas.

Interaction: Leaf anatomical characteristics possess taxonomic value, especially in species differentiation and identification, that can be subsequently useful in explaining plant's adaptation to their environment.

Key Words: Convolvulaceae, Ipomoea, Leaf adaptation, Leaf anatomy

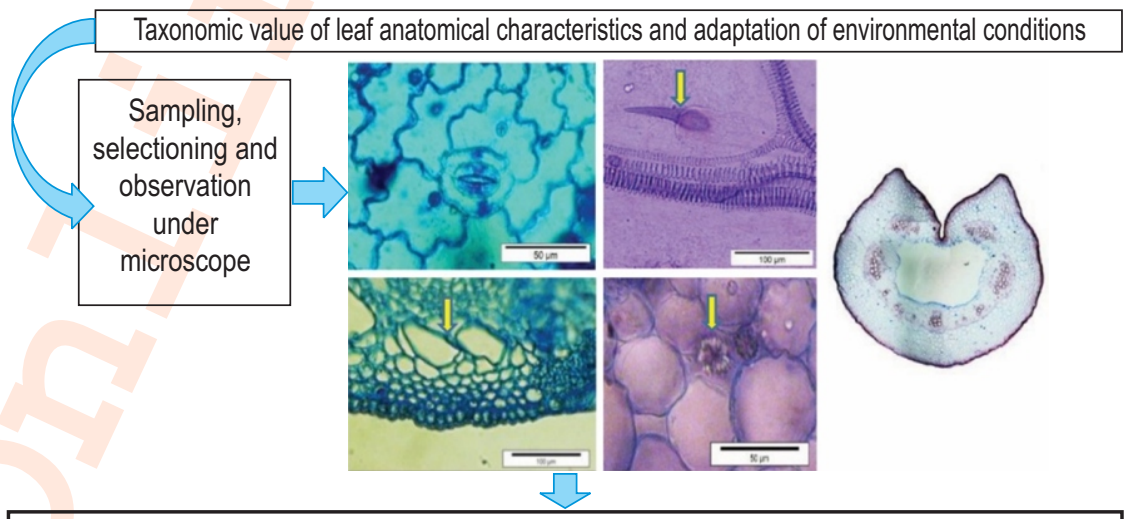

Identification and classification : In the type of leaf ve nation, in the presence of trichome and schlerenchyma cells, in the presence of mucilaginous idioblast cells in the petiole and midrib, in the presence and types of stomata, in the presence and type of trichomes and in the presence of druses. Anatomical adaptations to the environment: Presence of aerenchyma cells in I. pescaprae, I. purpurea and I. triloba, presence of epicuticular cuticles in I. pes-caprae and presence of air spaces in the petiole and steam of $I$. aquatica signified its floating ability.
\end{abstract}

How to cite : Noraini, T., A.J. Amirul-Aiman, A.R. Ruzi and S.F. Nurdiana: Adaptation and taxonomic value of leaf anatomical characteristics of selected Ipomoea L. species. J. Environ. Biol., 42, 872-878 (2021). 


\section{Introduction}

There are more than 650 species that can be found in the world (Jayeola and Oladunjoye, 2012; Judd et al., 2002; Miller et al., 2004), with 40 species in Malaysia (Khadijah et al., 2016). The species distribution is widely in tropical and subtropical countries (Austin and Huaman, 1996; Meira et al., 2012), but some can be found in temperate countries (Cao et al., 2005; Meira et al., 2012).

Ipomoea L. belongs to family Convolvulaceae has the largest number of species and is an ornamental plant because of their flowers (Jayeola and Oladunjoye, 2012). This genus consists of woody and herbaceous lianas, scandents, shrubs or small trees. The flower is campanulate, bisexual and actinomophic, with variations in petal colour from purple, red, pink, orange-reddish or white (Folorunso et al., 2013; Olorode 1984). Meanwhile, the fruit is oblong or globose in shape, capsulated with four to six seeds.

According to Noraini and Cutler (2007) and Ruzi et al. (2009), anatomical characteristics are alternative identification method beside morphological characteristics for many plant species. The presence of latex and parallel vascular bundles are the diagnostic characteristics of this genus (Folorunso et al., 2013; Shukla and Mistra 1979). The presence of resin glycoside is a chemotaxonomic bioindicator for Ipomoea within family Convolvulaceae (Meira et al., 2012; Wagner, 1973). Folorunso (2013) showed Ipomoea species can be divided into two groups on the types of stomata. The presence of brachyparacytic stomata is diagnostic in I. batatas, I. carnea, I. intrapilosa, I. asarifolia, I. nil, I. mauritiana, I. aquatica, I. triloba, I. alba and I. involucrata, the remaining species have paracytic stomata.

There is no previous study that relate Ipomoea leaf anatomical characteristics to the environment and on its' taxonomic significance to this genus. In view of the above, this study was conducted to investigate the leaf anatomical characteristics in Ipomoea species that were systematically significant and helpful in evolving anatomical adaptations to their environments.

\section{Materials and Methods}

Fresh leaf samples of Ipomoea were collected from different localities in Selangor, Malaysia (Table 1). The samples were fixed in ethanol and acetic acid in ratio 1:3). For leaf venation study, the leaf lamina was cleared using basic fuchsin solution and kept at $60^{\circ} \mathrm{C}$ in an oven for $1-2$ days, depending on the leaf specimen. Clear leaves were then dehydrated in alcohol series, soaked in xylene and mounted on slides using Canada balsam (R\&M Chemical, Essex, UK). The samples were then placed in an oven at $60^{\circ} \mathrm{C}$ for nearly 2 week. The slides were photographed with a digital camera (Olympus BX43F, Tokyo) mounted on Olympus microscope (Olympus Soft Imaging Solutions $\mathrm{GmbH}$, Münster, Germany). The leaf venation patterns were observed with Cell^B Software (Olympus Soft Imaging Solutions $\mathrm{GmbH}$, Münster, Germany) under 10x, 20x, 40x and 100x magnifications. Standard botanical microtechniques of Johansen (1940) and Sass (1958), were followed with slight modifications to mould the material. Leaf sectioning was conducted using a sliding microtome (thickness of 10-15 $\mu \mathrm{m}$ ). These sections were stained in safranin and alcian blue and then dehydrated in an alcohol series of $50 \%, 70 \%, 95 \%$ and $100 \%$. The specimens were then mounted on slides using euparal, followed by photography using an Olympus Diaphlan microscope. The images were processed using Analysis Docu Software.

\section{Results and Discussion}

All species studied had complete marginal venation, swollen tracheids, trichome at leaf margins and sclerenchyma cells in the petiole and midrib vascular bundles. The pattern of anticlinal cell walls observed in this study were straight-to-curve, curve-to-wavy, wavy-to-sinuous and sinuous (Table 2). According to Metcalfe and Chalk (1950), Convolvulaceae has straight-tosinuous anticlinal cell walls, while Folorunso (2013) stated that Ipomoea has sinuous anticlinal cell walls. Our study discovered other types of anticlinal cell walls. Based on Hong-zhi (2001), the pattern of anticlinal cells wall is rigid and genetically controlled. Ecological and biological specializations which have arisen in response to peculiarities of environment are of more limited use.

Table 1 : List of /pomoea species studied

\begin{tabular}{lll}
\hline Species & Code specimen & Locality \\
\hline I. batatas (L.) Lam. & FND01 & Rumah Tumbuhan, UKM, Bangi \\
& FND02 & Port Dickson, Negeri Sembilan \\
I. aquatica Forssk. & FND04 & TasikFKAB, UKM, Bangi \\
& FND05 & Kuala Selangor, Selangor \\
I. cairica (L.) Sweet & FND06 & Rumah Tumbuhan, UKM, Bangi \\
I. pes-caprae(L.) R. Br. & FND07 & Port Dickson, Negeri Sembilan \\
& FND08 & Kuala Selangor, Selangor \\
I. purpurea (L.) Roth. & FND09 & Tanah Rata, Cameron Highland, Pahang \\
& FND10 & Port Dickson, Negeri Sembilan \\
I. trilobaL. & FND11 & Rumah Tumbuhan, UKM, Bangi \\
\hline
\end{tabular}


However, Noraini et al. (2019) and Gunasegaran et al. (2021) reported that in the experience of systematic anatomists, although the structure of a species can and does vary with the habitat, anatomical variation in response to ecological change is much less marked than is commonly believed and is more often quantitative than qualitative.

Wilkinson (1979) stated that in dry and hot weather, plant species have straight anticlinal cell wall, especially on adaxial side whereas understorey plant is expected to have sinuous anticlinal cells wall on both adaxial and abaxial side (Mussury et al., 2012). Based on this study, I. pes-caprae was the most tolerable species in the hot and dry environment compared to others.

According to Metcalfe and Chalk (1979), stomata in Convolvulaceae is usually present on both abaxial and adaxial leaf epidermis or simply known as amphistomatic. This observation is supported by this research findings and corresponds with the study on I. cairica by Mandal et al. (2015). Three types of stomata were present in Ipomoea species studied; staurocytic, paracytic and anomocytic. Some species were homostomatic (where only one type of stomata was present), as present in I. batatas, I. pes-caprae, I. purpurea, Ipomoea triloba (all species had anomocytic stomata). Some species were heterostomatic (more than one type of stomata were present), as in I. aquatica (paracytic, anomocytic) and I. cairica (paracytic, anomocytic, staurocytic). Table 3 shows the stomata anatomical characteristics in /pomoea species studied.

Van Cotthem (1970) stated that stomata not only have diagnostic value but can also be related to natural surrounding. Devi et al. (2013) also agreed that variation and stomata type can be used in biological, ecological, and enviromental studies of plant species. Conclusively, our study corresponds with the findings by Folorunso et al. (2013) as Ipomoea has paracytic, anisocytic, and anomocytic stomata on both adaxial and abaxial leaf surface.

The outlines of leaf margin for I. purpurea, I. batatas, I. aquatica, I. cairica, I. purpurea and I. triloba were all round and recurved $10^{\circ}-30^{\circ}$ to abaxial side. Conversely, I. pes-caprae had acute outline. Therefore, this characteristic can be used to differentiate species in Ipomea. Table 4 shows variation in the outline of leaf margin in /pomoea species studied.

The presence of vascular bundles in the leaf margin was only observed in I. pes-caprae, which can be used as a diagnostic character for this species. Nevertheless, the vascular bundles were also observed in the leaf lamina, in the middle of leaf lamina in I. aquatica, I. pes-caprae, I. cairica and I. triloba, near to adaxial epidermis in $I$. batatas, and near to abaxial epidermis in $I$. pupurea. This character is useful for species differentiation in Ipomoea.
The number of palisade cells layer does not have systematic significant but this character is relatively related to the environment (Noraini, 2012). The number of palisade layers change according to light intensity (Ashton and Berlyn, 1992). Findings of this study discovered that all species studied had one layer of mesophyll palisade, except $I$. aquatica with 2-4 layers. Most species had one palisade layer cell representing $1 / 2$ thickness of leaf lamina, except for 1-3 layers in I. pes-caprae and 3-4 layers in I. purpurea. For spongy mesophyll, I. purpurea had three layers representing $1 / 4$ of leaf lamina thickness, $3-4$ layers in I. cairica and I. triloba, 4-5 layers in I. batatas, I. aquatica and I. pes-caprae.

According to Esau (1977), aerenchyma cells refer to plant tissue with intercellular or airy spaces. Aerenchyma cells were only present in the leaf lamina of $I$. pes-caprae, I. purpurea and $I$. triloba (Fig. 1D). The presence of intercellular or airy spaces in these three species have shown the leaf anatomical adaptation to aquatic habitat. Table 5 shows variation in the presence of aerenchyma, spongy mesophyll, and palisade layers in all species studied.

Metcalfe and Chalk (1950) stated that the common trichome present in family Convolvulaceae is glandular capitate trichomes, whilst simple and capitate glandular trichomes are found in the genus Ipomoea. In this study, trichome was found in the leaf margin, lamina and midrib. The type of trichomes found in this study were simple, peltate and capitate glandular trichomes (Fig. 1B). Variation in trichome types in all Ipomea species studied is presented in Table 6 .

Previous studies have shown that $I$. triloba and $I$. pescaprae have simple and glandular trichome (Ahmad et al., 2016). Folorunso et al. (2013) also reported that I. batatas and I. aquatica have glandular trichome but simple trichome is found in I. triloba. Our results support the findings of previous studies that the present and type of trichomes are proven can be used to differentiate Ipomoea species and this character definitely has taxonomic significant.

Calcium oxalate crystals can be found in many plant species (Doege, 2003). Classification at species and genus level can be done on the presence of crystals (Franceschi and Horner, 1980; Genua and Hillson, 1985; Hsieh and Huang, 1974; Noraini et al., 2016; Prychid and Rudall, 1999; Solederer, 1908). Sahreen et al. (2010) stated that cystals can be found in the paerenchyma cell wall and intercellular spaces in the form of solitory crystals or clusters. Metcalfe and Chalk (1950) reported that in Ipomoea, normally crystals can be found in clusters form (Fig. 1E). The availability of calcium oxalate crystals in all Ipomoea species studied is given in Table 7 .

Ipomoea is a group of plant species that has spesific anatomical characteristics in adapting extreme environment and 
Table 2 : Pattern of anticlinal cell wall of Ipomoea species studied

\begin{tabular}{lll}
\hline Species & \multicolumn{2}{c}{ Pattern of anticlinal cells wall } \\
\cline { 2 - 3 } & Adaxial epidermis & Abaxial epidermis \\
\hline l. batatas & Curve to sinuous & Sinuous \\
l. aquatica & Wavy to sinuous & Curve to sinuous \\
l. pes-caprae & Straight to curve & Straight to curve \\
l. cairica & Straight to curve & Sinuous \\
l. purpurea & Wavy to sinuous & Wavy to sinuous \\
l. batatas & Curve to sinuous & Sinuous \\
\hline
\end{tabular}

Table 3: Stomata anatomical characteristics in /pomoea species studied

\begin{tabular}{lll}
\hline Species & Presence & Types \\
\hline batatas & Amphistomatic and homostomatic & Anomocytic \\
aquatica & Amphistomatic and heterostomatic & Paracytic, Anomocytic \\
I. pes-caprae & Amphistomatic and homostomatic & Anomocytic \\
I. cairica & Amphistomatic and homostomatic & Anomocytic, staurocytic, paracytic \\
l. purpurea & Amphistomatic and homostomatic & Anomocytic \\
l.triloba & Amphistomatic and homostomatic & Anomocytic \\
\hline
\end{tabular}

Table 4 : Variation in the outline of leaf margin in /pomoea species studied

\begin{tabular}{ll}
\hline Species & Description \\
\hline I. batatas & Rounded, recurved $10^{\circ}$ to abaxial side \\
I. aquatica & Rounded, recurved $10^{\circ}$ to abaxial side \\
I. pes-caprae & Acute, recurved $10^{\circ}$ to abaxial side \\
I. cairica & Rounded, recurved $10^{\circ}$ to abaxial side \\
I. purpurea & Rounded, recurved $30^{\circ}$ to abaxial side \\
I. triloba & Rounded, recurved $10^{\circ}$ to abaxial side \\
\hline
\end{tabular}

Table 5 : Variation in the presence of aerenchyma cells, number of spongy mesophyll and pallisade cell layers in /pomoea species studied

\begin{tabular}{llll}
\hline Species & Number of palisade cell layers & Number of spongy mesophyll cell layers & Aerenchyma cells \\
\hline I. batatas & 1 & $3-4$ & Absent \\
I. aquatica & 1 & $2-4$ & Absent \\
I. pes-caprae & $4-5$ & 1 & Present \\
I. cairica & $4-5$ & $3-4$ & Absent \\
I. purpurea & 3 & 3 & Present \\
I. triloba & $3-4$ & $3-4$ & Present \\
\hline
\end{tabular}

Table 6 : Location and variation in trichome types in /pomoea species studied

\begin{tabular}{lllll}
\hline Species & Leaf margin & Lamina & Petiole & Midrib \\
\hline I. batatas & Capitate glandular, simple & Peltate glandular & Capitate glandular & Capitate glandular \\
I. aquatica & Peltate glandular & Capitate glandular & Capitate glandular & Capitate glandular \\
I. pes-caprae & Absent & Peltate glandular & Absent & Peltate glandular \\
I. cairica & Peltate glandular & Peltate glandular & Absent & Peltate glandular \\
I. purpurea & Peltate glandular & Simple & Simple, Peltate glandular & Simple, peltate glandular \\
l. triloba & Capitate glandular & Peltate glandular & Capitate glandular & Capitate glandular \\
\hline
\end{tabular}


Table 7 : Location and variation in the presence of calcium oxalate crystals

\begin{tabular}{llll}
\hline Species & Lamina & Petiole & Midrib \\
\hline I. batatas & Absent & Absent & Absent \\
I. aquatica & Absent & Absent & Druses \\
I. pes-caprae & Absent & Druses & Druses \\
I. cairica & Absent & Druses, solitory & Absent \\
I. purpurea & Druses & Druses & Druses \\
l. triloba & Druses & Druses & Absent \\
\hline
\end{tabular}

Table 8: Diagnostic leaf anatomical characteristics in /pomoea species studied

\begin{tabular}{ll}
\hline Species & Diagnostic characteristics \\
\hline I. batatas & Anticlinal cells wall curve or wavy. \\
I. aquatica & Anticlinal cells wall curve to sinuous on abaxial epidermis.Air spaces present in petiole pith. \\
I. pes-caprae & Epicuticular waxes present on leaf epidermisDruses presentin leaflamina. Outline of leaf margin acute. \\
I. purpurea & Anticlinal cells wall wavy to sinuous on abaxial epidermis.Simple trichome present in the petiole.Simple trichome on \\
& abaxial epidermis. \\
\hline
\end{tabular}
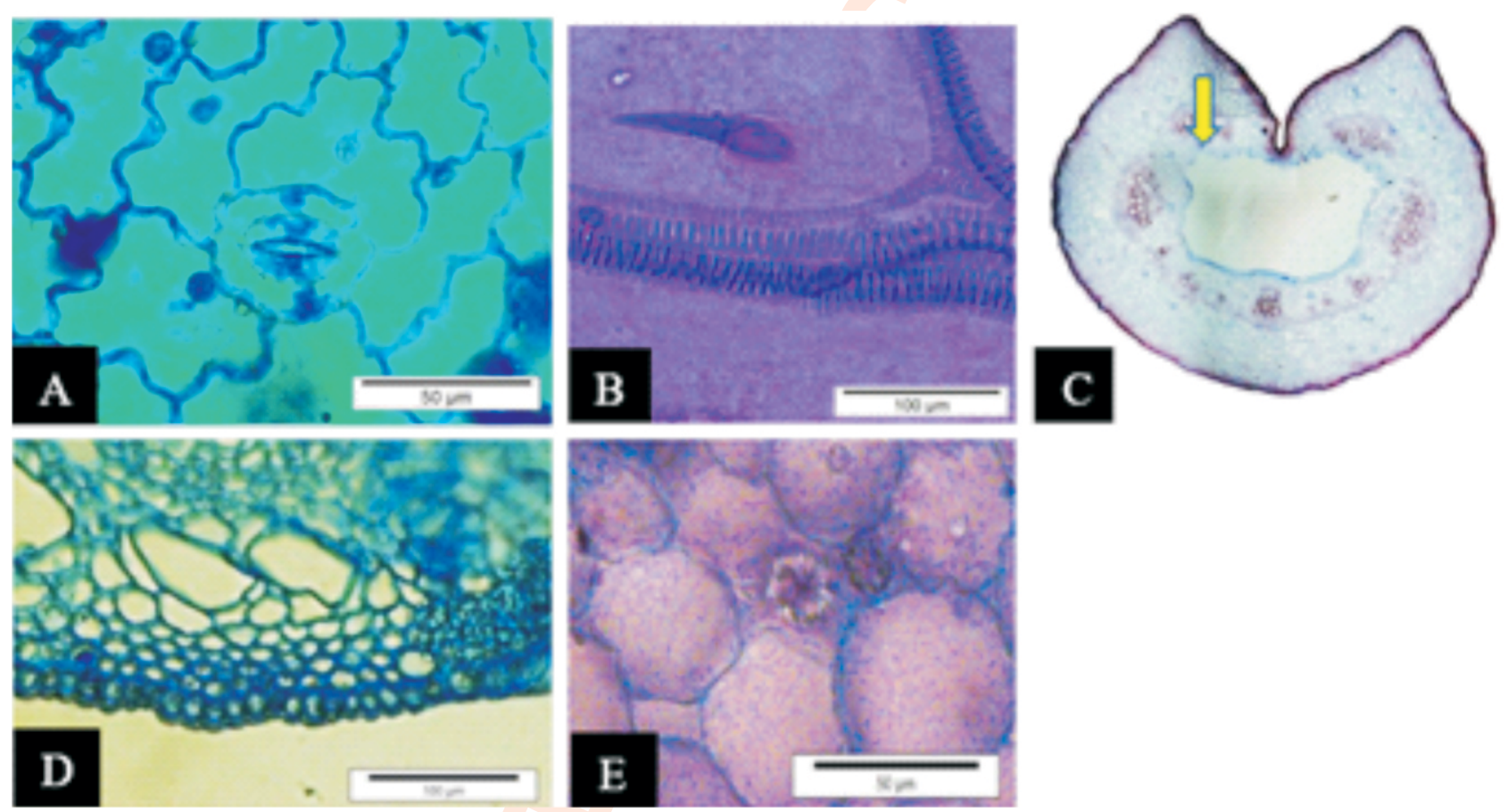

Fig. 1 : (A) Sinuous anticlinal cell wall in I. batatas; (B) Simple trichome in I. aquatica; (C)Air spaces in petiole pith of I. aquatica; (D) Aerenchyma in I. pescaprae and (E) Druses in I. pes-caprae.

surrounding. Ipomoea pes-caprae for example, is one of the species that has capability to adapt in sandy and salty area such as beach. This type of plant species is known as halophyte plant species. The presence of epicuticular wax is one of the mechanisms for coping extreme environment. This is similar to $I$. aquatica that adapts in aquatic area. This plant species is known as hydrophyte plant. The presence of aerenchyma cells help the hydrophyte plant to emerge above water.
Diagnostic characteristics are prominent in only one species, but this character has systematic significant that can be useful for identification of species (Noraini et al., 2017). Diagnostic leaf anatomical characteristics found in this study are tabulated in Table 8.

An identification key for Ipomoea species studied was constructed based on the leaf anatomical chacracteristics: 
Key to Ipomoea species studied based on leaf anatomical characteristics: Vascular bundles present in the middle of leaf lamina, glandular trichome present in the lamina and midrib. Vascular bundles adjacent to leaf epidermis, non glandular trichome present in the lamina and midrib Ipomoea purpurea; Outline of leaf margin rounded and recurved $10^{\circ}$ to $30^{\circ}$ to leaf abaxial side. Outline of leaf margin acute and recurved $10^{\circ}$ to leaf abaxial side, epicuticular waxes present on the leaf epidermis of $I$. pes-caprae; Aerenchyma cells absent in the leaf lamina, curve to sinuous, wavy to sinuous, or straight to curve anticlinal cell wall present on leaf epidermis adaxial side. Aerenchyma cells present in the leaf lamina, sinuous anticlinal cells wall present on leaf epidermis adaxial and abaxial side of $I$. triloba; Air spaces absent in the petiole pith, sinuous anticlinal cells wall present only on leaf epidermis abaxial side. Air spaces present in the petiole pith, druses present in the midrib of $I$. aquatica; Trichome present in the petiole, homostomatic, only anomocytic stomata present, druses and solitary crystals present in the petiole of $I$. batatas; Trichomes absent in the petiole, heterostomatic, anomocytic, staurocytic and paracytic stomata present, druses and solitary crystas present in the petiole of $I$. cairica.

The findings of this study definitely have shown that leaf anatomical characteristics in the studied genus has taxonomic value for species identification and classification, especially in the type of leaf venation, presence of trichomes and sclerenchyma cells, in the presence of mucilaginous idioblast cells in petiole and midrib, presence and types of stomata, presence and type of trichomes and presence of druses. Some anatomical adaptations to the environment were found in this study such as presence of aerenchyma cells in I. pes-caprae, I. purpurea and I. triloba, presence of epicuticular cuticles in I. pes-caprae and presence of air spaces in petiole and stem of $I$. aquatica signified its floating ability.

In conclusion, leaf anatomical characteristics have taxonomic value for species differentiation and identification, and also show leaf anatomical adaptation towards extreme environment.

\section{Acknowledgment}

Authors would like to thank grant GUP-2017-035 and FRGS/1/2019/STG03/UKM/02/3 for funding this research.

\section{Add-on Information}

Authors' contribution : T. Noraini: Analysis of anatomical characteristics; A.J. Amirul-Aiman: Processing data on anatomy and habitat; A.R. Ruzi: Taxonomic area on Ipomoea; H. Bunawan: Using some facilities and techniques on equipment in INBIOSIS; S.F. Nurdiana: M. Sc. student working on this project.

Research content : The research content of manuscript is original and has not been published elsewhere.

\section{Ethical approval : NotApplicable}

Conflict of interest: The authors declare that there is no conflict of interest.

\section{Data from other sources : NotApplicable}

Consent to publish : All authors agree to publish the paper in Journal of Environmental Biology.

\section{References}

Ahmad, I., E. Boran Abo and M. Majboor: Characteristics anatomical features of some Ipomoea species in Sudan. In : Proceedings of Seventh Graduate Studies and Scientific Research, Faculty of Science, University of Khartoum, Sudan, pp. 1-19 (2016).

Ashton, P.S. and G.P. Berlyn: Leaf adaptations of some Shorea species to sun and shade. New Phytol., 121, 587-596 (1992).

Austin, D.F. and Z. Huáman: A synopsis of Ipomoea (Convolvulaceae) in the Americas. Taxon, 45, 3-38 (1996).

Cao, S., R.C. Guzza, J.H. Wisse, J.S. Miller, R. Evans and D.G.I. Kingston: Ipomoeassins A-E, cytotoxic macrocyclic glicoresins from the leaves of Ipomoea squamosa from the Suriname rainforest. J. Nat. Prod., 68, 487-492 (2005).

Devi, N.S., Y. Padma, C.L. Narasimhudu and R.R. Venkata Raju: Diversity of stomata and trichomes in Euphorbia L. I. BJPT, 20, 2738 (2013).

Doege, S.J.: The role of natural calcium oxalate crystals in plant defense against chewing insects. Inquiry, 4, 88-94 (2003).

Esau, K.: Plant Anatomy, $2^{\text {nd }}$ Edn., John Wiley and Sons, NY, USA (1977).

Folorunso, A.E., H.C. Illoh and J. Olorungbeja: Numerical taxonomy of some Ipomoea (L.) species in South-West Nigeria. IJS, 15, 34-46 (2013).

Folorunso, A.E.: Taxonomic evaluation of fifteen species of Ipomoea L. (Convolvulaceae) from south-western Nigeria using foliar micromorphological characters. Not. Sci. Biol., 5, 156-162 (2013).

Franceschi, V.R. and H.T. Horner: Calcium oxalate crystals in plants. Bot Rev., 46, 361-427 (1980).

Genua, J.M. and C.J. Hillson: The occurrence, type and location of calcium oxalate crystals in the leaves of four-teen species of Araceae. Ann. Bot., 56, 351-361 (1985).

Gunasekaran, D., T. Noor Idayu, A. Muhamad Afiq, B. Syazwani, I. Ismanizan, T. Noraini, R. Ahmad Bazli, B. Syarul Nataqain, M.N. Normah, B. Hamidun: Discovery of anthocyanin biosynthetic pathway in Cosmos caudatus Kunth using omics analysis. Agronomy, 11, 661-684 (2021).

Hong-Zhi, K.: Comparative morphology of leaf epidermis in the Chloranthaceae. Bot. J. Linn. Soc., 136, 279-294 (2001).

Hsieh, C.F. and T.C. Huang: The Acantaceous Plants of Taiwan. Taiwania, 19, 19-57 (1974).

Jayeola,A.A. and O.R. Oladunjoye: Systematic studies in some Ipomoea L. species using pollen and lower morphology. Annals of West University of Timişoara, Series of Biology, 15, 177-187 (2012).

Johansen, D.A.: Plant Microtechnique. McGraw-Hill Book Company, Inc, New York (1940).

Judd, S.W., S.C. Campbell, A.E. Kellogg, F.P. Stevens and J.M. Donoghue: Plant Systematics: A Phylogenetic Approach. $2^{\text {nd }}$ Edn., Sinauer Associates, Inc., Massachusettes (2002).

Khadijah, A., M.A. Mohd Shukri, A. Mohd Nor, M. Siti Sofiah, O. Mohd 
Khairuddin, M.N. Anuar Rasyidi and M. Mohd Khairulazhar: Kepelbagaian spesies keledek liar (Ipomoea Linnaeus) di Semenanjung Malaysia. Persidangan Kebangsaan Agrobiodiversiti 2016 - NAC 2016, Malaysian Agricultural Research and Development Institute (MARDI), Malaysia (2016).

Mandal, S., C.H. Rahman and C. Sutapa: Studies on Ipomoea cairica L. (Sweet) - A promising ethnomedicinally important plant. J. Innov. Pharm. Biol. Sci., 2, 378-395 (2015).

Meira, M., P.D.S. Eliezer, J. M. David and J.P. David: Review of the genus Ipomoea: Traditional uses, chemistry and biological activities. Rev. Bras. Farmacogn., 22, 682-713 (2012).

Metcalfe, C.R. and L. Chalk: Anatomy of Dicotyledon. Volume 2. Clarendon Press, Oxford (1979).

Miller, R.E., J.A. McDonald and P.S. Manos: Systematics of Ipomoea subgenus quamoclit (Convolvulaceae) based on ITS sequence data and a bayesian phylogenetic analysis. Am. J. Bot., 91, 1208$1218(2004)$.

Mussury, R.M., Z.V. Pereira and S.D.P.Q. Scalon: Comparison of leaf morphoanatomy of Diodella radula (Willd. \& Hoffmanns. Ex Roem. \& Schult.) Delprete and Diodella teres (Walter) Small (Rubiaceae). Int. J. Plant Res., 2, 41-45 (2012).

Noraini, T., A.R. Mohamad Ruzi and A.J. Muhammad Amirul Aiman: Anatomi dan Mikroskopik Tumbuhan. Penerbit UKM, Bangi (2019).

Noraini, T. and D.F. Cutler: Systematic significance of petiole and midrib anatomical characters in Parashorea (Dipterocarpaceae) of Malaysia. Malays. Appl. Biol., 36, 47-55 (2007).

Noraini, T., A.R. Ruzi, M.K. Nurnida and N.R. Hajar: Systematic Significance of leaf anatomy in Johannes teijsmannia H.E. Moore (Arecaceae). Pertanika J. Trop. Agric. Sci., 35, 223-235 (2012).

Noraini, T., A.R. Ruzi, B.S. Ismail, B. Ummu Hani, S. Salwa and J. Azi Azeyanty: Petiole vascular bundles and its taxonomic value in the tribe Dipterocarpeae (Dipterocarpaceae) Sains Malays., 45, 247-253 (2016).

Noraini, T., G. Mohd Norfaizal, A. Latiff, H. Masrom, S. Salmaniza and M.R. Nurshahidah: Comparative studies of leaf venation in some species of Sapindaceae of Malaysia. Malays. Appl. Biol., 46, 115127 (2017).

Olorode, O.: Taxonomy of WestAfrican flowering plants. Longman Group Ltd., London, pp. 88-89 (1984).

Prychid, C.J. and P.J. Rudall: Calcium oxalate crystals in monocotyledons: A review of their structure and systematics. Ann. Bot., 84, 725-739 (1999).

Ruzi, A.R., K. Hussin and T. Noraini: Systematic significance of the petiole vascular bundles types in Dipterocarpus Gaertn. F (Dipterocarpaceae). Malays. Appl. Biol., 38, 11-16 (2009).

Sahreen, S., M.A. Khan, M.R. Khan and R.A. Khan: Leaf epidermal anatomy of the genus Silene (Caryophyllaceae) from Pakistan. Pak. J. Bot., 3, 93-102 (2010).

Sass, J.E.: Botanical Microtechnique. $3^{\text {rd }}$ Edn., Oxford \& IBH Publishing Co., Calcutta (1958).

Shukla, P. and S.P. Mistra: An Introduction to the Taxonomy of Angiosperms. Vikas Ltd., New Delhi, pp.447-448 (1979).

Solederer, R.: Systematic Anatomy of the Dicotyledons. Clarendon Press, Oxford (1908).

Van Cotthem, W.R.J.: A classification of stomatal types. Bot. J. Linn. Soc., 63, 235-246 (1970).

Wagner, $\mathrm{H} .:$ Chemistry in botanical classification: Medicine and natural sciences. In: The Chemistry of Resin Glycosides of the Convolvulaceae (Eds.: G. Bendz and J. Santesson). Academic Press, New York and London, 235 pages (1973).

Wilkinson, H.P.: The plant surface (mainly leaf). Part I: Stomata. In: Anatomy of the Dicotyledons. (Eds.: C.R. Metcalfe and L. Chalk). $2^{\text {nd }}$ Edn. The Clarendon Press, Oxford, pp. 97-167 (1979). 